\title{
Myrmecodesmus hastatus (Schubart, 1945), a widespread Neotropical millipede (Diplopoda, Polydesmida, Pyrgodesmidae)
}

\author{
Sergei I. GolOVATCH* and Joachim ADIS** \\ *Institute for Problems of Ecology and Evolution, Russian Academy of Sciences, Leninsky pr. 33, \\ 119071 Moscow(V-71),Russia; e-mail: sgol@orc.ru \\ **Max-Planck-Institute for Limnology, Tropical Ecology Working Group, Postfach 165, D-24302 Plön, Germany; \\ e-mail: adis@mpil-ploen.mpg.de
}

\begin{abstract}
The distribution of the small-bodied millipede Myrmecodesmus hastatus (Schubart, 1945), which currently covers much of South America, is reviewed and refined with the first records from Peru and Mato Grosso state, Brazil. Generally, this species seems to be so strongly associated with ant and termite nests that synanthropization might have also contributed to the species' extensive range due to host range expansions.
\end{abstract}

Key words: Diplopoda, Myrmecodesmus, myrmecophily, termitophily, synanthropization, South America

\section{INTRODUCTION}

The millipede Myrmecodesmus hastatus was first described as the type, and sole constituent species of the genus Gonographis Schubart, 1945: G. hastata Schubart, 1945, from Distrito Federal, Brazil. A little later, the same species was again described as new: Lophodesmus inquilinus Silvestri, 1947, from one place in Argentina and two in Brazil (Silvestri 1947). Their formal synonymy was advanced by Schubart (1954).

Hoffman (1985) described another Gonographis, G. adisi Hoffman, 1985, a semiaquatic species from near Manaus, Amazonas, Brazil. Further two congeners, G. minuscula Golovatch, 1997 and G. duodecimlobata Golovatch, 1997, were added, both from near Manaus as well, and this genus was believed endemic to South America (Golovatch 1997). Finally, Golovatch (2000) has synonymized Gonographis with Myrmecodesmus Silvestri, 1910 and formally transferred all four erstwhile Gonographis species to Myrmecodesmus, i.e. M. hastatus, M. adisi, M. minusculus, and $M$. duodecimlobatus. These are still the only species of this genus known from South America proper.

As a result, Myrmecodesmus as currently accepted is a highly species-rich and variable genus with as many as 11 generic synonyms and more than 30 valid species (cf. Hoffman 1999). The distribution pattern of this genus is thus pan-Neotropical, ranging from Florida, Alabama, Mississippi, Louisiana and Texas in the U.S.A. (Shelley 2004) in the north to Argentina in the south. The bulk of Myrmecodesmus species diversity is confined to Central America together with the Caribbean, whereas both southern North America and entire South America seem to support depauperate faunas. However, in South America at least, in contrast to any other congener, one of the four currently described species appears to have attained a particularly vast distribution, a fact accounted for by its presumably particular ecological traits. This species is $M$. hastatus. Below is a review concerning its geography and ecology as based both on published records, and new material accumulated in recent years.

ZMUM stands for the collection of the Zoological Museum of the Moscow State University, Russia, while CA for Collection of Joachim Adis, Plön, Germany. 


\section{DISTRIBUTION}

\section{Myrmecodesmus hastatus (Schubart, 1945)}

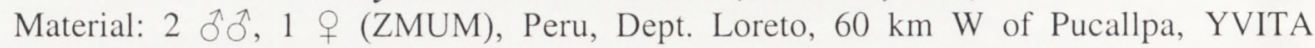
Research Station, pasture, Pheidole sp. anthill, 18.03.1986, leg. A.A. Zakharov. - numerous ô. 우 (CA, ZMUM), Brazil, Mato Grosso, Cuiaba, garden, 20.06.1999, leg. L. Wilck (see also Adis et al. 2003).

Remarks: This species appears to be extremely widespread over much of South America, being associated with human settlements, gardens, plantations as well as termitaria and ant nests. It has hitherto been encountered in the following places.

Brazil: Distrito Federal, Maciço da Tijuca, garden at Furnas (Schubart 1945); São Paulo, Mun. Pirassununga, Cachoeira de Emas, estates, gardens, banana plantations; Mun. Mogiguassú, Mogi-Guassú, estate and garden (Schubart 1944, 1947b, 1952); São Paulo City, Vila Mariana, "cupinseiro" and ant nests; Mun. Itanhaem, Santa Clélia Farm, banana plantation and in Pheidole anthills; Mun. Barretos, Colômbia, gardens (Schubart 1947b, 1954; Silvestri 1947); Pará, Mun. Belém, Aurá, under a tree downtown and in orchard (Schubart 1947a, 1947b); Bahia, Brotas, Anoplotermes reconditus termitarium (Silvestri 1947); Rio de Janeiro, Mun. São Gonzales, Fazenda Engenho Novo (Schubart 1954).

Argentina: Prov. Tucumán, Tucumán, in Solenopsis anthills (Silvestri 1947; Schubart 1954).

The above new samples represent the first formal records of $M$. hastatus in Peru and in Mato Grosso state, Brazil. Furthermore, based on the above evidence, one can readily presume that $M$. hastatus is actually much more common in Amazonia and other places in South America, Brazil first of all. The occurrence of this species in Paraguay and/or Bolivia, located in between Tucumán and the sites in Brazil, is also quite plausible. All currently known records are shown on Map. Future collecting efforts undertaken in various urban, agricultural and other disturbed habitats, especially in search for symphiles of anthills and termitaria, are certain to reveal this small pyrgodesmid species (5-6 $\mathrm{mm}$ in length) as being one of the most usual, widespread and characteristic myrmeco- and termitophiles in the Neotropics.

\section{REVIEW OF MYRMECODESMUS HASTATUS ECOLOGY}

The above records show clear-cut inclinations of $M$. hastatus to dwelling in open habitats, often if not always in association with ants and/or termites. Among Myrmecodesmus, as implied by the generic name alone, there are several species that can be termed as formiand/or termiticoles. Some of these, like numerous other examples of myrmeco- or termitophily, are indeed relatively widespread, especially when the host species of ant or termite occupies a wide geographical area (cf. Schubart 1947b). This concerns at least $M$. formicarius Silvestri, 1910, known from Vera Cruz, Mexico north and east through the Texas coastal plain as far as Louisiana, U.S.A. (Hoffman 1999, Shelley 2004). However, M. hastatus appears to be especially widely distributed, ranging over much of South America from Amazonia in the north to northern Argentina in the south (Fig. 1). Apparently, this can be accounted for not only by the symphily of $M$. hastatus with ants and termites but also by its presumably high-level tolerance to desiccation, implying a particularly hard exoskeleton and probably certain morphological modifications of the cuticula and spiracles. Yet, using SEM techniques, superficially no peculiar/meaningful traits have been found in $M$. hastatus vis-à-vis two such ecologically different congeners from Brazilian Amazonia as M. duodecimlobatus (Golovatch, 1997), from terra firme woodlands, and M. adisi (Hoffman, 1985), a semiaquatic species from whitewater inundation forest (Adis et al. 2003). 


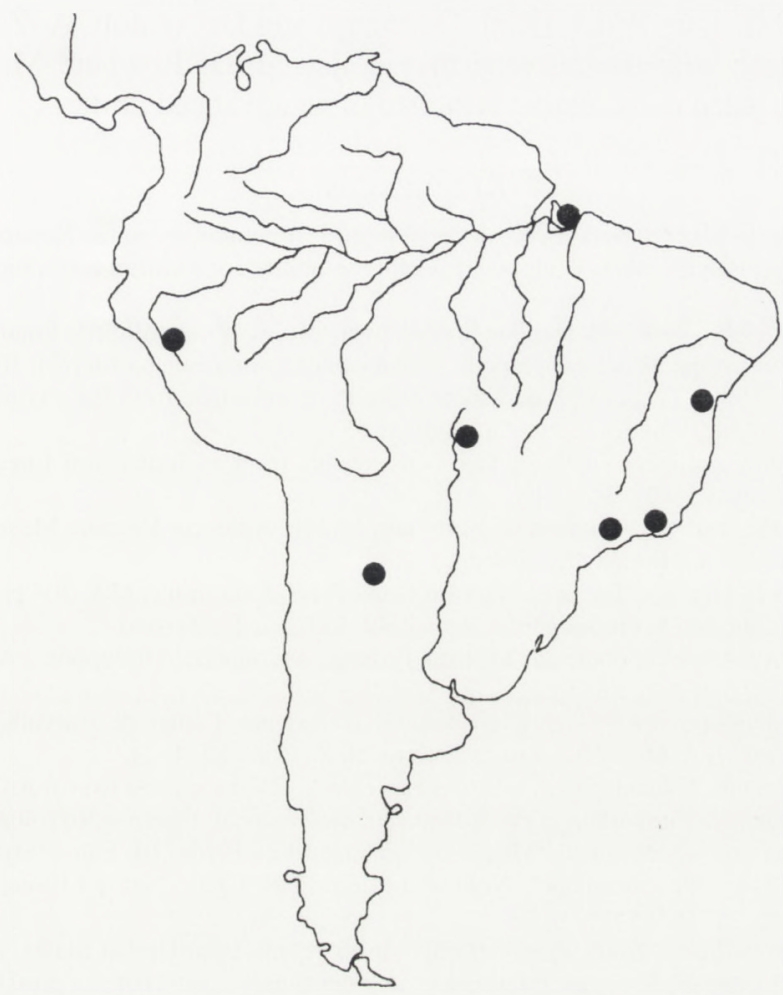

Fig. 1. Places of occurrence of Myrmecodesmus hastatus (Schubart, 1945).

Indeed, in the tropics, open terrain is known to be much drier than forest habitats. Also, like any deteriorated/secondary environment, open biotopes, including urbanized and agricultural ones, support disproportionately high numbers but fewer species of ants as compared to woodlands. This phenomenon of ant superdomination is the more impressive as ants generally dominate any tropical forest in terms of both animal population density and species richness (e.g., Holldobler \& Wilson 1990). Keeping this in mind, it is hardly surprising that the millipede species $M$. hastatus, probably a facultative(?) symbiont of ants and termites, many of which are known to be adapted to disturbed to completely man-made environments, has successfully colonized, often if not always following their host(s), a very wide range of secondary habitats like grasslands, parks, gardens, orchards, plantations and urbanized places. This has been accompanied by a significant geographical range expansion as well, one that currently covers much of South America. The range is presently so extensive that it is virtually impossible to unequivocally outline a possible source/origin area for $M$. hastatus, though this seems more likely to have lain somewhere in northern South America, closer to Central America, the epicenter of Myrmecodesmus species diversity. In this connection, the above record of M. hastatus in the upper reaches of Amazon River within Peru is of particular interest.

In general, as both myrmeco- and termitophily amongst tropical Diplopoda are particularly characteristic of Pyrgodesmidae (Schubart 1947b, Silvestri 1947), one can easily suggest that the unique, pan-Neotropical distribution pattern of the genus Myrmecodesmus as a whole may have become realized, at least in part, through close association of some of its constituent species with ants and/or termites. 


\section{ACKNOWLEDGMENTS}

Our thanks go to Mr. Lars Wilck (Kiel, Germany) and Dr Anatoly A. Zakharov (Moscow, Russia) for supplying us with the material they collected. Dr Rowland M. Shelley (Raleigh, U.S.A.) has kindly provided constructive criticism of an advanced draft.

\section{REFERENCES}

Adis J., Golovatch S. I. \& Messner B. 2003. Morphological structures in some Neotropical Myrmecodesmus species (Pyrgodesmidae, Polydesmida, Diplopoda) reveal the ability for plastron respiration. Arthropoda Selecta 12(1): 17-21.

Golovatch S. I. 1997 (for 1996). Two new and one little-known species of the millipede family Pyrgodesmidae from near Manaus, Central Amazonia, Brazil (Diplopoda, Polydesmida). Amazoniana 14(1/2): 109-120.

Golovatch S. I. 2000 (for 1999). On six new and some older Pyrgodesmidae from the environs of Manaus, Central Amazonia, Brazil (Diplopoda, Polydesmida). Amazoniana 15 (3/4): 221-238.

HofFMAN R. L. 1985. A new millipede of the genus Gonographis from an inundation forest near Manaus, Brazil (Pyrgodesmidae). Amazoniana 9(2): 243-246.

HofFMAN R. L. 1999. Checklist of the millipeds of North and Middle America. Virginia Museum of Natural History Special Publication Number 8, Martinsville, 584 pp.

Holldobler B. \& Wilson E. O. 1990. The ants. Harvard Univ. Press, Cambridge, MA, 304 pp.

Schubart O. 1944. Os Diplopodos de Pirassununga. Acta Zool. Lilloana 2: 321-440.

Schubart O. 1945. Os Proterospermophora do Distrito Federal (Myriapoda, Diplopoda). Arq. Mus. Nac. Rio de Janeiro 38: 1-156.

SCHUBART O. 1947a. Os Diplopoda da viagem do naturalista Antenor Leitão de Carvalho aos rios Araguaia e Amazonas en 1939 e 1940. Bol. Mus. Nac. Rio de Janeiro, N. S., Zool. 82: 1-74.

SCHUBART O. 1947b. O elemento "synanthropo" e estrangeiro entre os Diplopoda do Brasil. Arthropoda 1(1): 23-40.

SCHUBART O. 1952. Diplopoda de Pirassununga IV. Adenda a fauna regional. Dusenia 3(6): 403-420.

SChubart O. 1954. Diplópodos argentinos del Museo de la Ciudad Eva Perón. III. Fam. "Stylodesmidae”. IV. Fam. "Cryptodesmidae". V. Fam. "Polydesmidae". Notas del Museo, Fac. Cienc. Nat. y Museo, Univ. Nac. Eva Perón 17(155): 347-358.

ShEllEY R. M.. 2004. The milliped family Pyrgodesmidae in the continental United States, with the first record of Poratia digitata (Porat) from the Bahamas (Diplopoda: Polydesmida). J. nat. Hist. (in press)

Silvestri F. 1947. Contributo alla conoscenza dei Diplopodi termitofili dell'America meridionale. Boll. Lab. Ent. Agr. Portici 8: 1-32.

\section{STRESZCZENIE}

\section{[Myrmecodesmus hastatus (Schubart, 1945) - gatunek krocionoga (Diplopoda, Polydesmida, Pyrgodesmidae) szeroko rozprzestrzeniony w Neotropiku]}

W pracy dokonano analizy i oceny rozmieszczenia niewielkiego krocionoga Myrmecodesmus hastatus (Schubart, 1945). Aktualnie, jego rozprzestrzenienie obejmuje większość kontynentu Ameryki Południowej. W analizie uwzględniono ostatnie dane z Peru i stanu Mato Grosso w Brazylii. Gatunek ten wydaje się być ścisle związany z gniazdami mrówek i termitów. Dlatego rozszerzenie zasięgu tych krocionogów może wynikać również z ekspansji gospodarzy związanej z ich synantropizacją. 